\title{
ASSESSING GROUNDWATER RECHARGE IN TWO SITES WITH DIFFERENT CLIMATES IN THE ALICANTE REGION OF SOUTH-EAST SPAIN
}

\author{
MIGUEL FERNÁNDEZ-MEJUTO ${ }^{1,2,3}$, JOSÉ MIGUEL ANDREU²,3, \\ CONCEPCIÓN PLA ${ }^{3,4}$ \& JAVIER VALDÉS-ABELLÁN ${ }^{3,4}$ \\ ${ }^{1}$ Hydrologic Cycle, Diputación Provincial de Alicante, Spain \\ ${ }^{2}$ Department of Earth Sciences and Environment, University of Alicante, Spain \\ ${ }^{3}$ Water and Environmental Science Institute, University of Alicante, Spain \\ ${ }^{4}$ Department of Civil Engineering, University of Alicante, Spain
}

\begin{abstract}
The province of Alicante is mainly occupied by rocks of carbonated nature. This implies that most of the provincial groundwater resources are located in aquifers of karstic nature. Due to the geological characteristics of the area, these aquifer systems show a wide variety of lithologies, rock ages and reservoir geometry (both in extension and thickness). In addition, these aquifers are distributed in a region with an important rainfall gradient between the north, with recorded average annual rainfall of about $900 \mathrm{~mm}$, and the south, with averages of about only $300 \mathrm{~mm}$. Thus, there is a strong contrast in terms of underground resources, more abundant towards the north of the province. In this study, two aquifers have been selected to stablish the influence of the climate regime and of karstic development on their recharge processes, and therefore in their resources. Both are of small dimensions, well monitored and have a similar hydrogeological behavior. The main objective has been to estimate the recharge in each of them and to evaluate to what extent climate and soil affects this variable. To achieve it, a soil water balance model, called RENATA, has been used. The two aquifers selected are the aquifer of Ventós-Castellar, located in one of the most arid areas of the province where average annual rainfall is around $300 \mathrm{~mm}$, and the Mela aquifer, located in a more humid environment with an average annual rainfall around $600 \mathrm{~mm}$.
\end{abstract}

Keywords: soil water budget, karstic aquifer, recharge, RENATA model, Ventós-Castellar, Mela, Alicante.

\section{INTRODUCTION}

The province of Alicante, in the south-east of Spain, is a region whose economy has been largely supported by groundwater due to the lack of surface water. During the last decades, groundwater has allowed large agrarian transformations, as well as a strong industrial, urban and touristic development. Nowadays $51.8 \%$ of the volume supplied as drinking water to 1.7 million of inhabitants comes from groundwater, and $40 \%$ of agriculture is irrigated with this type of water [1].

Most of the groundwater comes from carbonated aquifers. Unlike other places, in Alicante province the high tectonic complexity has resulted in a high hydrogeological compartmentalization. Thus, there is a large number of aquifers in Alicante but most of them with small or medium extension. Despite this fact, many of these aquifers have had and still have great importance at local or district scales, since their waters are the only available for urban supply or irrigation. Therefore, it is relevant to try to get better the understanding of these aquifers and especially of the mechanisms and quantification of their recharge. This might help the water-resources manager in the development of sustainable water polices.

However, recharge estimation to the aquifers is a complex task [2]-[5], but this task is can be harder in karstic aquifers because they are heterogeneous systems and there are several mechanisms of recharge interacting [6]. Generally, it can be considered that the main source for recharge of karstic aquifer comes from rainfall infiltration, but the mechanisms for 
infiltration can be multiple. Factors such as variability of porosity and permeability, land use, slope, land use, soil and vegetation cover, between others, determine if infiltration is mainly diffuse, concentrated or both. This means that each aquifer has its own particularities regarding the type and magnitude of the recharge. In addition, groundwater recharge is highly dependent of the climatic conditions not only because the total rainfall volume, but the intensity and yearly distribution of rainfall events as well determine the recharge. Precipitation in the Mediterranean region has a strong inter-annual variability. It is typical the alternance of long dry periods with intense rainfall events. These are responsible for most of recharge volumes to the aquifer [7], [8], if not all. But even within the same climatic region, differences between precipitation patterns and evapotranspiration regime in different sectors can change dramatically recharge processes.

During the last decades many efforts have been done in the search for methodologies suitable to estimate recharge accurately and operatively. Numerous, direct and indirect, approaches have been used in karst aquifers [9]-[14]. One of the most commonly applied methods is the soil water balance. This methodology has been widely used around the Mediterranean context and specially in several carbonated aquifers of the Betic Cordillera with good results [14]-[18], and thus, this the approach applied for this study.

\section{OBJECTIVES}

The main aim of the present study has been to estimate recharge in two small karstic and assess the factors influencing the recharge processes. This kind of karst aquifers located in different Mediterranean environments are strongly dependent of local climatic conditions and of their geological features (soil, faults, karst development). To model recharge and compare results between both test sites distributed models of groundwater recharge have been applied, using the modelling software called RENATA.

The selected test sites were specifically chosen to evaluate the climatic influence on recharge for the following reasons: both are small karstic systems whose conceptual models are relatively simple and well known; the resources of these aquifers are exclusively attributed to infiltration on permeable outcrops and their response to rainfall event is quick enough to facilitate the comparison of recharge volumes and water table levels/spring drainages evolution; moreover, both have been monitored for decades, and reasonably accurate measurements of rainfall, temperature and other climatic parameters are available. These characteristics allow to calibrate the recharge model.

\section{CLIMATIC CHARACTERISTICS OF THE ALICANTE PROVINCE}

Its latitude, coastal location and orographic configuration determine climatic differences in the province of Alicante. Broadly, the region shows typical Mediterranean climate with mild temperatures and long and sometimes extreme summer drought. But locally climates range between semi-arid to sub-humid conditions throughout its geography. The northern region, whose rains are distributed irregularly throughout the year, presents a temperate humid regime, while the southern part is characterized by a semi-arid regime, with small amounts of precipitation usually concentrated in a small number of yearly events.

The topography plays a key role in the pluviometric distribution. The reliefs, with a general guideline SW-NE and with strong slopes, intercept the humid air flows of the E from the Mediterranean, causing its elevation and cooling and, consequently, triggering precipitations. Broadly speaking, there is a double rainfall gradient with maximum values in the NE of the province, that markedly decrease to $\mathrm{S}$ and $\mathrm{W}$, reaching its minimum values in the coastal areas of the S. In addition to the spatial irregularity, the province is characterized by a strong seasonality and episodes of high intensity storms. These intensities are associated 
with the convective nature of most of the rainy events, especially in autumn. The high relative temperature of the waters of the Mediterranean Sea after the summer warming favors the formation of warm, very humid and unstable air masses, which precipitate sharply.

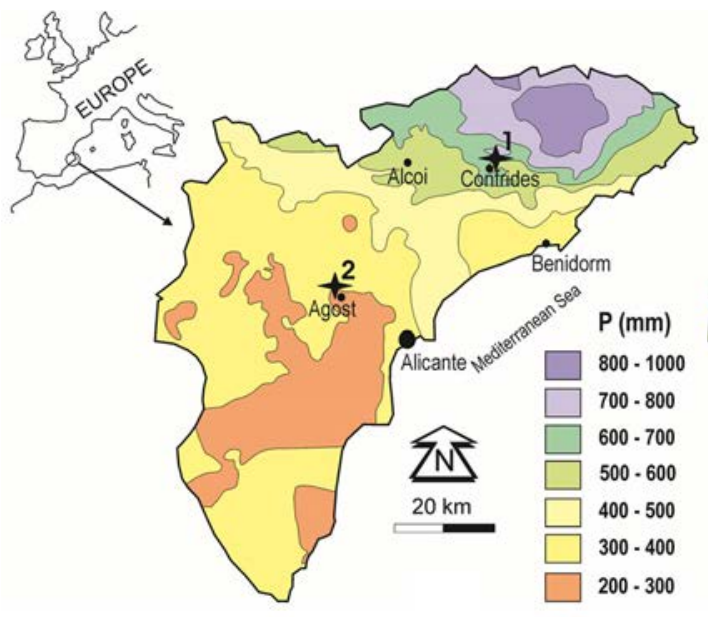

(a)

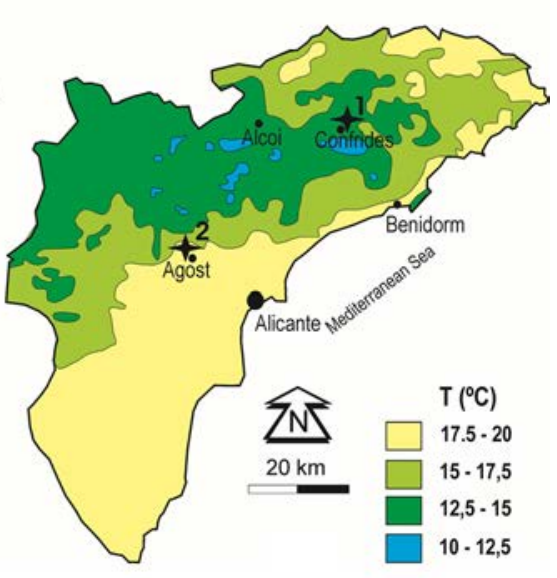

(b)

Figure 1: Geographic and climatic sites. (a) Mean annual precipitation; (b) Mean annual temperature. 1. Ventós-Castellar aquifer 2. Mela aquifer. (Source: Data from Spanish Meteorological Agency (AEMET) [19].)

All these factors result in averages close to $1,000 \mathrm{~mm}$ in the NE areas, that decrease in the southwest direction where average rainfall is less than $300 \mathrm{~mm}$ per year. The seasonal distribution of rainfall is determined by the autumn maximum (the wet season accumulates between $40 \%$ and $50 \%$ of the total annual rainfall) that follows the summer minimum (around $10 \%$ of annual rainfall).

As for precipitation, temperature is defined by altitude, distance to the sea and latitude. The lowest temperatures are recorded in the interior lands with average annual values lower than $15^{\circ} \mathrm{C}$, while in the littoral, they are around $18^{\circ} \mathrm{C}$. In the coastal areas the winters are very mild and rarely temperatures drop below $0^{\circ} \mathrm{C}$. However, inland the average daily minimum winter records fall to relatively low values, between $4^{\circ} \mathrm{C}$ and $6^{\circ} \mathrm{C}$. The maximum values, with an annual average around $18.5^{\circ} \mathrm{C}$, descend slightly towards the north, reaching $17.5^{\circ} \mathrm{C}$.

Provincial $\mathrm{ET}_{0}$ (or ETP) values are high, with average values ranging between 900 and $1,400 \mathrm{~mm} \mathrm{yr}^{-1}$ [19]. The highest values are concentrated in the areas of least precipitation, which means that the evaporative demand of the atmosphere is greater than rainfall. This characteristic situation of semi-arid zones is anomalous in the rest of Europe and places the province of Alicante in one of the areas with the greatest scarcity of water resources [20]. All this causes a situation of water deficit that reaches its maximum towards the south of the province in accordance with the hours of insolation and the thermal regime.

\section{GEOGRAPHIC AND CLIMATIC AQUIFER SETTINGS}

Mela aquifer is a representative example of systems located in the humid part of the province. It is located in the northern of the province $\left(38^{\circ} 42^{\prime} 11.7^{\prime \prime} \mathrm{N}, 0^{\circ} 16^{\prime} 03.6^{\prime \prime} \mathrm{W}\right)$ near Confrides and between Alcoi and Benidorm. It is a tiny aquifer coincident with a small relief called Solancia 
de Mela which barely has $1.04 \mathrm{~km}^{2}$. This aquifer drainage is used for water supply of El Abdet, a small district of Confrides. For the studied period (1981-2017) mean annual temperature accounts for $16.14^{\circ} \mathrm{C}$ and mean annual precipitation for $605 \mathrm{~mm}$, although ranges between 195 and 1,200 $\mathrm{mm} \mathrm{yr}^{-1}$. Finally, potential evapotranspiration according to FAO Penman-Monteith accounts for $1,145 \mathrm{~mm}$.

Ventós-Castellar aquifer is located in the central part of the province where the weather is typically semiarid. The aquifer is beside Agost town near Alicante city $\left(38^{\circ} 28^{\prime} \mathrm{N}, 0^{\circ} 37^{\prime} \mathrm{W}\right)$. This aquifer extent of about $7 \mathrm{~km}^{2}$ largely corresponds with the Ventós and Castellar mountain ranges, whose altitudes range between 300 to $840 \mathrm{~m}$ a.s.l. Nowadays water from this aquifer is used for water supply of Agost. This region presents long drought periods which alternate with short wet events and hot dry summers followed short mild winters. In this case, average temperature is $18.1{ }^{\circ} \mathrm{C}$ and may vary from $8^{\circ} \mathrm{C}$ in January to $28^{\circ} \mathrm{C}$ in August. Potential evapotranspiration has an average value of $1,320 \mathrm{~mm}$ that ranges between 1,168 and 1,656 $\mathrm{mm} \mathrm{yr}^{-1}$. Rainfall average for the studied period is $281 \mathrm{~mm} \mathrm{yr}^{-1}$. Records show that rainy days number range between 20 and 70 days per year. These for the most part correspond to isolated low-intensity events. Rainfall episodes often do not exceed $20 \mathrm{~mm}$.

\section{HYDROGEOLOGICAL SETTINGS}

Mela aquifer is part of the hydrogeological unit of Sierra de Aitana in the north of the province. This domain integrates at least 40 aquifers of different size and lithological nature and one of them, in the northern sector of the domain, is Mela aquifer.

It is a karstic aquifer developed mainly on limestones and calcarenites of the Lower Cretaceous belonging to the Prebetic domain of Betic Cordillera. These carbonated materials outcrop as a small topographic elevation in the landscape surrounded by softer marls. This relief is part of a large anticline structure of E-W direction called Serrella anticline. The calcarenites and limestones that make up the Mela aquifer are located in the core of this anticline, which is also broken by some faults in a direction parallel to the axis of the anticline (Fig. 2(a)).

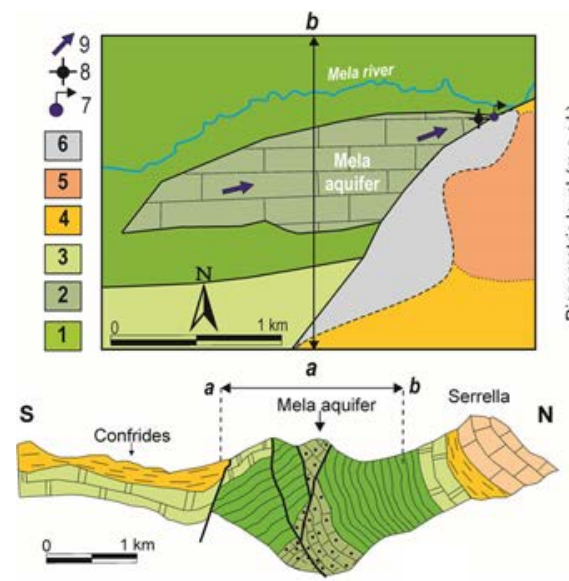

(a)

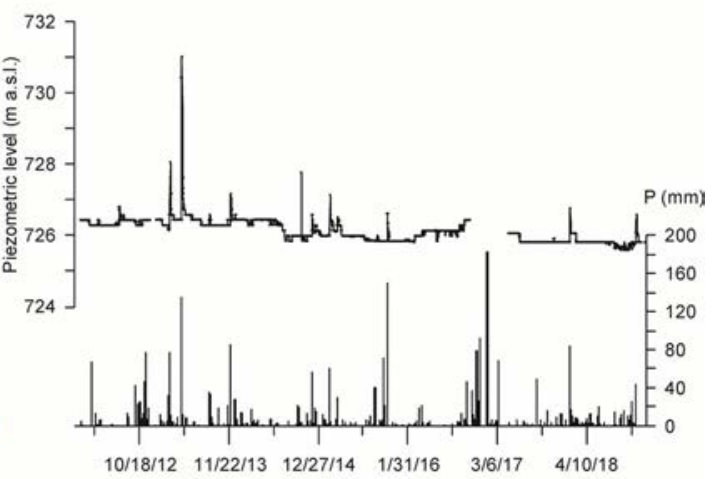

(b)

Figure 2: Hydrogeological settings of Mela aquifer. Legend: 1. Calcarenites and limestones (Lower Cretaceous); 2. Marls (Lower Cretaceous); 3. Limestones (Upper Cretaceous); 4. Marls (Paleocene-Eocene); 5. Limestones (Eocene); 6. Quaternary; 7. Mela spring; 8. Well; 9. Groundwater flow. 
The Cretaceous carbonates are totally disconnected from other aquifer units by marls with impervious behavior [21], [22]. The permeable nature of this formation allows part of the precipitation it receives, both liquid and in the form of snow, to infiltrate and move inside them. The only input this aquifer has is rainfall infiltration. The aquifer is working in natural regime, so that all the water that enters it ends up coming naturally through the spring of Mela. This spring is located in the NE of the aquifer, in the point where the aquifer materials outcrop with lower elevation. Near this point there is a well which was built to regulate the spring discharge. However, the pumping has seldom worked. This point is nowadays used as a piezometer to control the water table evolution. Fig. 2(b) shows the piezometric evolution in this point for the last six years. Water level presents certain stability which is truncated by instantaneous ascents, which present a good correlation with events of precipitation.

Ventós-Castellar aquifer is formed by Prebetic geological formations. This aquifer is constituted by $80-120 \mathrm{~m}$ of micritic limestones and white limestones from Albian to Upper Cretaceous. These terrains are folded forming a synclinal structure whose main axis is tilted to the SW. The aquifer is completely isolated from other aquifers of this region. In the Northern, Southern and Eastern boundaries the carbonates of the aquifer are in contact with Cretaceous and Tertiary marls (Fig. 3(a)). In the Western the limit of the aquifer is caused by a fault.

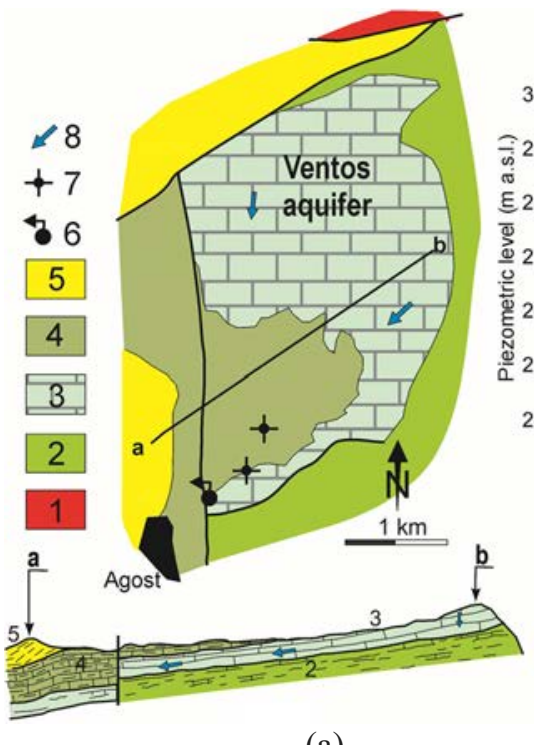

(a)

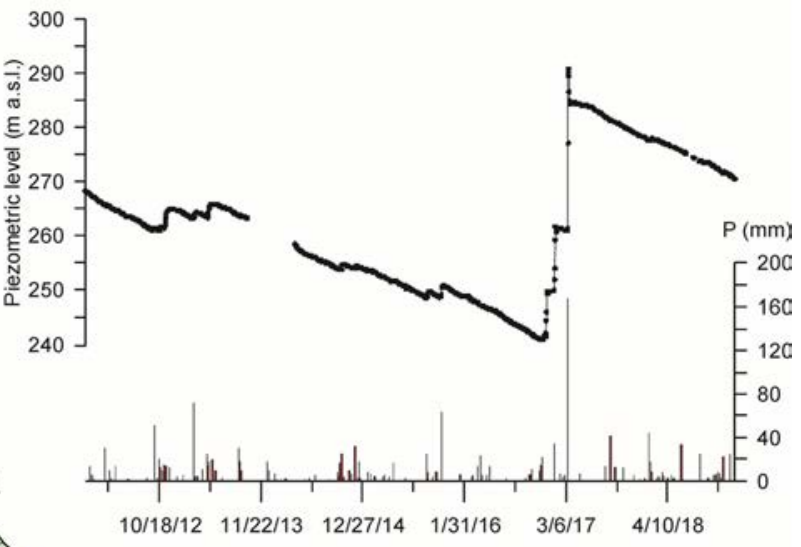

(b)

Figure 3: Hydrogeological settings of Ventós-Castellar aquifer. Legend: 1. Clay and gypsum (Triassic); 2. Marls (Lower Cretaceous); 3. Limestones (Cretaceous); 4. Marls and limestones (Upper Cretaceous); 5. Marls (Tertiary); 6. Inactive spring; 7. Well; 8. Groundwater flow.

This geological structure controls the hydrological behavior of the aquifer, which is relatively simple. Recharge exclusively takes place on the northern limestone outcrops. Then subterranean flow is directed quickly to the southwestern part of the aquifer where the spring was located. In natural regime the discharge took place through that point. At present the 
spring is inactive. It dried shortly after starting the pumping operations at the end of the seventies. The outputs were produced only by a single well. Although initial pumps were unknown, these rates were significant enough to contribute a significant emptying of the aquifer. Nowadays, the pumps are between 150,000 and $200,000 \mathrm{~m}^{3} \mathrm{yr}^{-1}$.

Fig. 3(b) shows water table evolution in the well equipped with an automatic piezometric register. Exploitation causes a continuous descend of the aquifer water table level and rainfall episodes cause a sudden change in this dynamic. The recovery of water table level is function of precipitation magnitude. The effects on the water table are observed within few hours after each storm what shows very fast dynamics. The structure and the geometry of the aquifer as well as the fractures of its carbonate rocks have been argued as responsible of the hydrodynamic of this aquifer [23]-[25].

\section{METHODOLOGY}

To assess recharge in both aquifers soil water balance models have been used. The code used is called RENATA ("REcarga NATural de Acuíferos"- Natural Aquifer Recharge), that has been developed by the Provincial Council of Alicante together with the IGME [26]. The greatest advantage of this application is that it allows to simulate recharge with several variations of the classic Thornthwaite model coupled with a Curve Number model, which combines simplicity and reduced data requirements with refinements of the classic model. All the options are available in an environment of discretized and distributed parameters and input data both in space and time.

RENATA inputs include climatic data, soil parameters and even the possibility of introducing irrigation if necessary. Daily precipitation, maximum, minimum and daily average air temperature are the basic input data required, while the parameters that model soil are the maximum available soil water content and the curve number. All these data are introduced as time series, in the case of climatic data and series used for calibration, such as observed water table levels and spring drainages, or as cartographic layers in the case of climatic sectors, soil characteristics of the irrigation data.

Potential evapotranspiration (ETP or $\mathrm{ET}_{0}$ ) can be computed, from the temperature data, by any of the methods available in the RENATA software: Thornthwaite, Hargreaves, Penman or Blaney-Criddle. Actual evapotranspiration and effective rainfall are computed by using potential evapotranspiration and rainfall data either with the Thornthwaite balance method (and the improvement introduced by Girard) [26].

Actual evapotranspiration (ETR) is the amount of water that actually returns to the atmosphere. Its value depends on the water availability, both as rainfall and as soil-water storage. The upper limit of ETR is defined by ETP. Effective rainfall is the sum of runoff and infiltration water. Thornthwaite method proposes that for each time period total rainfall is the sum of ETR, effective rainfall and increase/decrease of the soil-water storage usable by plants, parametrized by the maximum available soil-water storage also called field capacity.

In this study a variant of the Thornthwaite balance method devised by Girard has been used as better suited to what happens in nature [26]. This variant consists on considering that the excess rainfall is stored in two soil reservoirs. If the volume of water stored in the previous period $\left(R_{i-1}\right)$ is less than a certain value $R M I N$, then the excess rainfall $\left(E X_{i}=P_{i}-E T R_{i}\right)$ is completely stored (reservoir one). Either if $R_{i-1}$ is between $R M I N$ and a maximum value ( $R M A X$, equal to field capacity), $E X_{i}$ is divided between a portion to increase the soil water storage (of reservoir two) and the other portion added to superficial runoff.

Infiltration and surface runoff are computed by decomposing effective rainfall according to the Curve Number methodology of the USA Soil Conservation Service. 
Map algebra between the previous layers (climate, soil and irrigation) results an "intersections layer". Each intersection represents a group of cells with the same input and parameter data. The outputs of the model are obtained both for the full aquifer extent and for each intersection. Outputs include, actual evapotranspiration, infiltration, runoff and irrigation drainage to the aquifer.

Recharge is equivalent to the infiltration output plus irrigation excess, but it is potential recharge, in case that there is no irrigation on the aquifer.

Rainfall data, as well as average, maximum and minimum temperatures were obtained from AEMET and SIAR network. All gauging points are located near the aquifers. Though, the lack of continuous data for the studied period has made necessary to complete series with other meteorological stations by using regression techniques. Soil parameters, which play an essential role in recharge estimations, have been calibrated in the model with the reference of values obtained from previous work effectuated on the aquifers.

\section{RESULTS AND DISCUSSION}

Models have been calibrated with the recharge values, obtained from the series of spring drainage and well exploitation, and with average recharge values for the aquifers obtained in previous studies [1], [22].

The aquifer of Mela receives an average annual infiltration of $0.3 \mathrm{hm}^{3} \mathrm{yr}^{-1}$, this means an average of $325 \mathrm{~mm} \mathrm{yr}^{-1}$ of the total amount of $605 \mathrm{~mm} \mathrm{yr}^{-1}$ of rainfall. A $30 \%$ of the years recharge is under $0.2 \mathrm{hm}^{3} \mathrm{yr}^{-1}$ and a $39 \%$ is over 0.4 , being only a $31 \%$ the years closer to the average with values between 0.2 and $0.4 \mathrm{hm}^{3} \mathrm{yr}^{-1}$.

Fig. 4 shows a yearly summary of the major components of the soil water balance in $\mathrm{mm}$. It should be outlined the high value of recharge, about $54 \%$ of total rainfall. This behavior is due to the nature of the outcrop of the aquifer, basically karstic limestone without soil or vegetation.

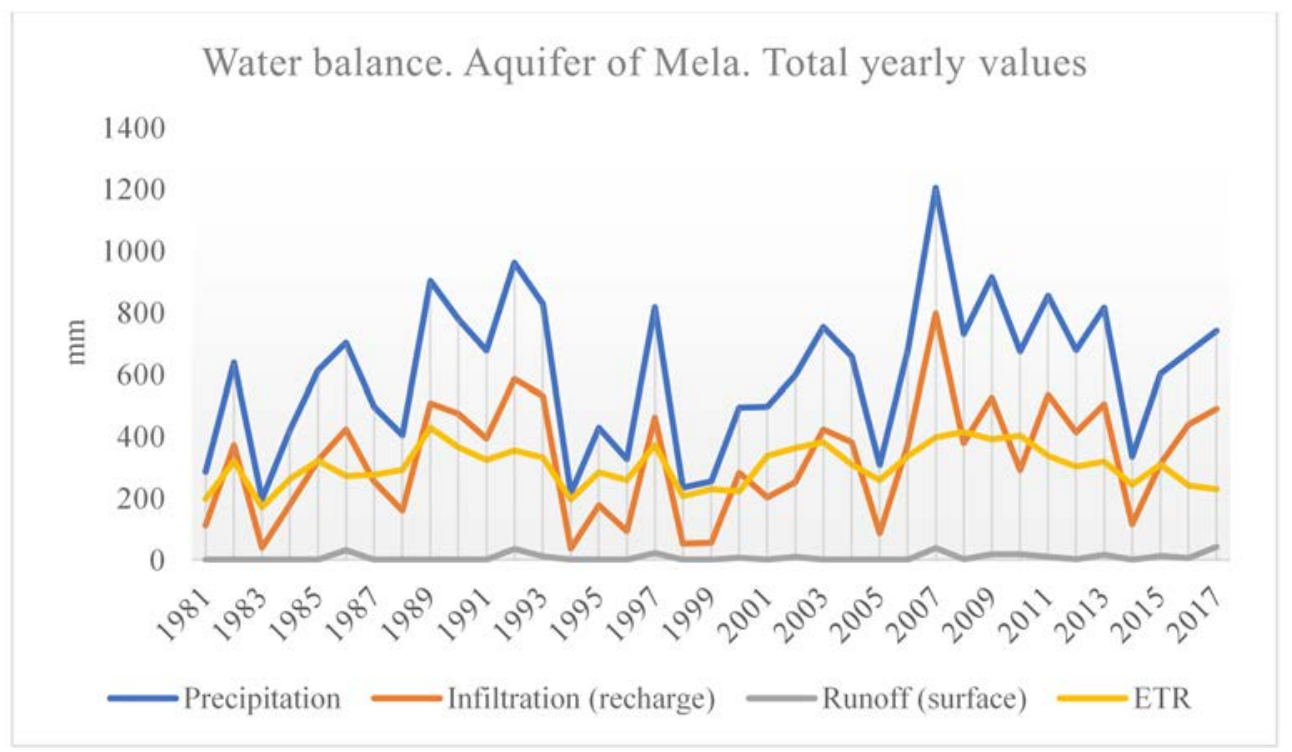

Figure 4: Soil water balance results for the aquifer of Mela. 
The layer of soil used in RENATA can be seen in Fig. 5. Two kind of soils have been identified. $83 \%$ of the total outcrop area are limestones without soil nor vegetal cover, and the rest has a very thin soil (less than $1 \mathrm{~m}$ ) and not dense Mediterranean forest with small trees and bushes. The calibration of the model shows that both materials are highly permeable, and in the case of limestones the virtual absence of soil determines very small storage susceptible of suffering evapotranspiration.

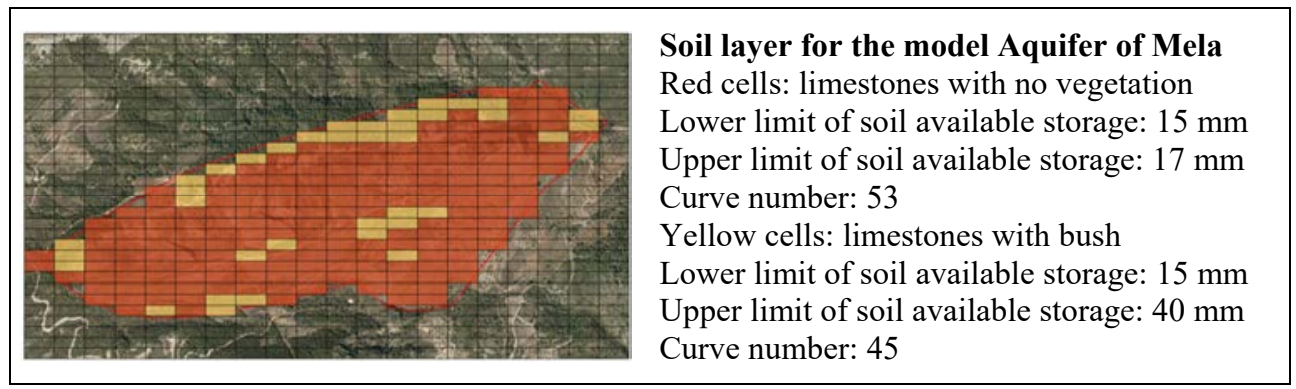

Figure 5: Layer for soils of the aquifer of Mela with the values of the parameters for the calibrated model.

This behavior implies that the model is not very sensible to the method of estimation of potential evapotranspiration, and minimal differences are found between using series calculated with Thornthwaite, Blaney-Criddle or Penman-Monteith. On the other hand, the curve number is a critical parameter, because it determines the distribution between surface runoff and infiltration. This distribution, due to the $\mathrm{CN}$ values is close to $50 \%$ (Fig. 6).

\section{Water balance. Aquifer of Ventós-Castellar. Total yearly values}

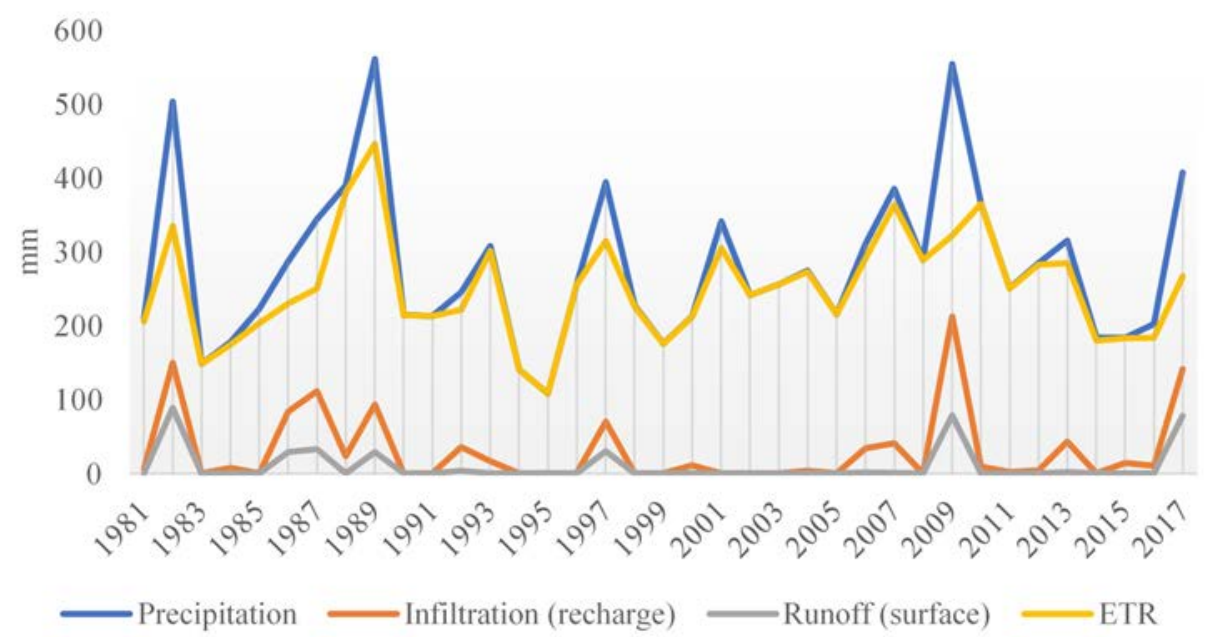

Figure 6: Soil water balance results for the aquifer of Ventós-Castellar. 
The aquifer of Ventós-Castellar (Fig. 6) has an average annual infiltration of only $0.2 \mathrm{hm}^{3} \mathrm{yr}^{-1}$ being in surface several times bigger than Mela. This is an average of $33.3 \mathrm{~mm} \mathrm{yr}^{-1}$ of the total amount of $281 \mathrm{~mm} \mathrm{yr}^{-1}$ of rainfall. A $40 \%$ of the years recharge negligible and a $22 \%$ is over $50 \mathrm{~mm} \mathrm{yr}^{-1}$.

The behaviour of this aquifer is explained not only for the rainfall regime, small amount of rainfall and events of small quantity very prone to evapotranspiration, but also for the nature of the outcropping material (Fig. 7). The presence of impervious materials and some soil development determines a high rate of superficial runoff and high evapotranspiration.

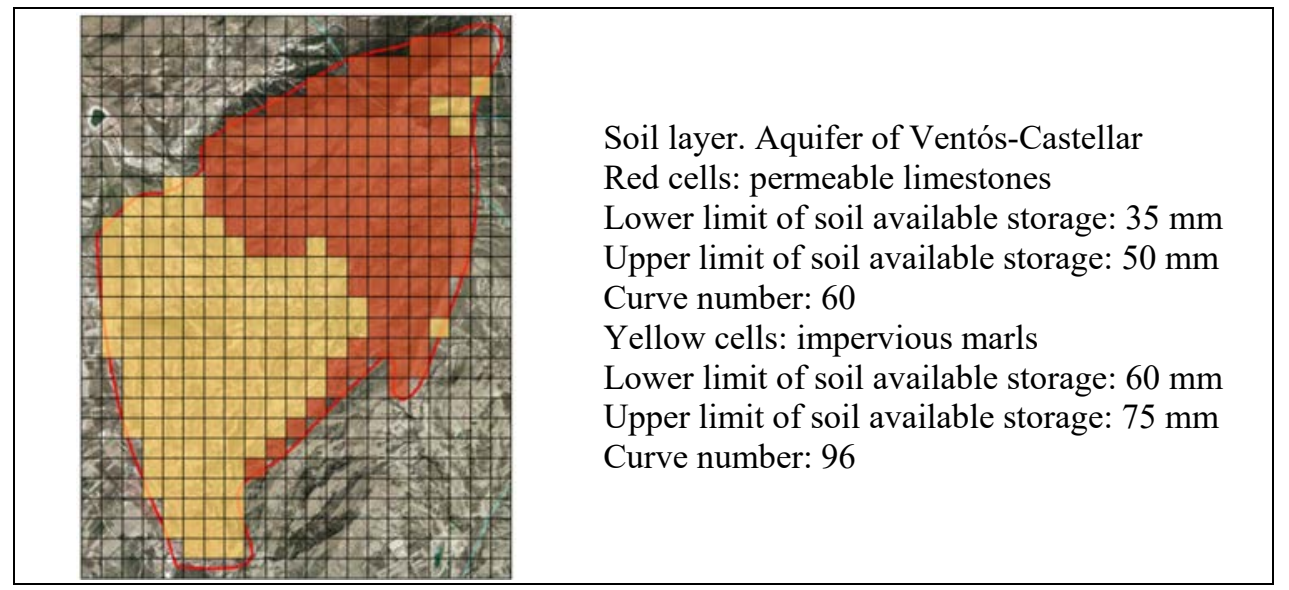

Figure 7: Layer for soils of the aquifer of Ventós-Castellar with the values of the parameters for the calibrated model.

\section{CONCLUSIONS}

Specific studies on small and well-known aquifers with different climates and geological features are required to set up models that can be extrapolated to estimate recharge in aquifers with uncertainties, due to its size or to lack of data.

Soil balance water models are a useful tool while readily applicable. The comparison of estimation methods, sensitivity analysis and the use of a two reservoirs soil model has given a good insight of how the process of recharge takes place in two limestone aquifers.

Different climate affects to how evapotranspiration withdraw moisture from the soil, but it is not the major factor defining recharge in these two aquifers. It is the behaviour of the soil storage, or the lack of soil in case of the aquifer of Mela where direct recharge prevails, the key element to determine recharge. These different factors change dramatically recharge rates, over $50 \%$ of total rainfall in case of Mela and about a $15 \%$ for the permeable outcrops of Ventós-Castellar.

Further research is required to characterize soil water storage and to obtain accurate regional estimations.

\section{ACKNOWLEDGEMENT}

This work has been carried out within the framework of the ALTERACLIM project (CGL2015-69773-C2-1) financed by the Ministry of Economy, Industry and Competitiveness. 


\section{REFERENCES}

[1] DPA (ed.), Mapa del Agua, Provincia de Alicante, Diputación de Alicante, 2007.

[2] Healy, R.W., Estimating Groundwater Recharge, Cambridge University Press, 2010.

[3] De Vries, J.J. \& Simmers. I., Groundwater recharge: An overview of processes and challenges. Hydrogeology Journal, 10(1), pp. 5-17, 2002.

[4] Scanlon, B.R., Healy, R.W. \& Cook, P.G., Choosing appropriate techniques to estimate groundwater recharge. Hydrogeology Journal, 10(1), pp. 18-39, 2002.

[5] Lerner, D.N., Issar, A.S. \& Simmers, I., Groundwater Recharge: A Guide to Understanding and Estimating Natural Recharge, IAH International Contributions to Hydrogeology 8, CRC Press, 1990.

[6] Bakalowicz, M., Karst groundwater: A challenge for new resources. Hydrogeology Journal, 13, pp. 148-160, 2006.

[7] Hartmann, A., Mudarra, M., Andreo, B., Marín, A., Wagener, T. \& Lange, J., Modeling spatiotemporal impacts of hydroclimatic extremes on groundwater recharge at a Mediterranean karst aquifer. Water Resources Research, 50, pp. 6507-6521, 2014.

[8] Moutahir, H., Bellot, P., Monjo, R., Bellot, J., Garcia, M. \& Touhami, I., Likely effects of climate change on groundwater availability in a Mediterranean region of Southeastern Spain. Hydrological Processes, 31(1), pp 161-176, 2017.

[9] Jukic, D. \& Denic-Jukic, V.D., A frequency domain approach to groundwater recharge estimation in karst. Journal of Hydrology, 289, pp. 95-110, 2004.p

[10] Andreo, B., Vías, J., Durán, J.J., Jiménez, P., López-Geta, J.A. \& Carrasco, F., Methodology for groundwater recharge assessment in carbonate aquifers: application to pilot sites in southern Spain. Hydrogeology Journal, 16, pp. 911-925, 2008.

[11] Geyer, T., Birk, S., Liedl, R. \& Sauter, M., Quantification of temporal distribution of recharge in karst systems from spring hydrographs. Journal of Hydrology, 348, pp. 452-463, 2008.

[12] Guardiola-Albert, C. et al., Comparison of recharge estimation methods during a wet period in a karst aquifer. Groundwater, 53(6), pp. 885-895, 2015.

[13] Allocca, V., Manna, F. \& De Vita, P., Estimating annual groundwater recharge coefficient for karst aquifers of the southern Apennines (Italy). Hydrology and Earth System Sciences, 18, pp. 803-817, 2015.

[14] Hartmann, A., Gleeson, T., Rosolem, R., Pianosi, F., Wada, Y. \& Wagener, T., A large-scale simulation model to assess karstic groundwater recharge over Europe and the Mediterranean. Geoscientific Model Development, 8, pp. 1729-1746, 2015.

[15] Zagana, E., Kuells, C.U. \& Constantinou, C., Methods of groundwater recharge estimation in eastern Mediterranean: A water balance model application in Greece, Cyprus and Jordan. Hydrological Processes, 21(18), pp. 2405-2414, 2007.

[16] Andreu, J.M., Alcalá, F.J., Vallejos, A. \& Pulido-Bosch, A., Recharge to aquifers in SE Spain: Different approaches and new challenges. Journal of Arid Environment, 75, pp. 1262-1270, 2011.

[17] Martos-Rosillo, S., González-Ramón, A., Jiménez-Gavilán, P., Andreo, B., Durán, J.J. \& Mancera, E., Review on groundwater recharge in carbonate aquifers from SW Mediterranean (Betic Cordillera, S Spain). Environment and Earth Science, 74, pp. 7571-7581, 2015.

[18] Estrada, B. \& Aragón, R., Estimación de la recarga de acuíferos mediante la aplicación de un código de balance hídrico (Sierra de Aitana, Alicante). Bol. Geol. Min., 117, pp. 593-595, 2006. 
[19] AEMET, Iberian Climate Atlas. Air temperature and precipitation (1971-2000). Spanish Agency of Meteorology. http://agroclimap.aemet.es/\#. Accessed on: 20 Apr. 2019.

[20] Wriedt, G. \& Bouraoui, F., Towards a General Water Balance Assessment of Europe. European Commission Joint Research Centre Institute for Environment and Sustainability: Italy. https://core.ac.uk/download/pdf/38615956.pdf.

[21] Valdés-Abellán, J., Pla, C., Fernández-Mejuto, M. \& Andreu, J.M., Validating the KAGIS black-box GIS based model in a Mediterranean karst aquifer: Case study of Mela aquifer (SE Spain). Hydrological Processes, 32, pp. 2584-2596, 2017.

[22] IGME-DPA (eds), Atlas Hidrogeológico de la Provincia de Alicante, Diputación de Alicante, 2015.

[23] Andreu, J.M. et al., Caracterización del funcionamiento y la recarga del acuífero del Ventós-Castellar (Alicante). Revista de la Sociedad Geológica de España, 14(3-4), pp. 247-254, 2001.

[24] Martínez-Santos, P. \& Andreu, J.M., Lumped and distributed approaches to model natural recharge in semiarid karst aquifers. Journal of Hydrology, 388, pp. 389-398, 2010 .

[25] Touhami, I. et al., Recharge estimation of a small karstic aquifer in a semiarid Mediterranean region (southeastern Spain) using a hydrological model. Hydrological Processes, 27(2), pp. 165-174, 2013.

[26] DPA-IGME (eds), RENATA: Recarga Natural a los Acuíferos, Diputación de Alicante, 2012. 